\title{
A conceptual framework of impression management: new insights from psychology, sociology and critical perspectives
}

Merkl-Davies, D.M.; Brennan, N.

\section{Accounting and Business Research}

\author{
DOI: \\ $10.1080 / 00014788.2011 .574222$
}

Published: 25/05/2011

Peer reviewed version

Cyswllt i'r cyhoeddiad / Link to publication

Dyfyniad o'r fersiwn a gyhoeddwyd / Citation for published version (APA):

Merkl-Davies, D. M., \& Brennan, N. (2011). A conceptual framework of impression management: new insights from psychology, sociology and critical perspectives. Accounting and Business Research, 41(5), 415-437. https://doi.org/10.1080/00014788.2011.574222

\section{Hawliau Cyffredinol / General rights}

Copyright and moral rights for the publications made accessible in the public portal are retained by the authors and/or other copyright owners and it is a condition of accessing publications that users recognise and abide by the legal requirements associated with these rights.

- Users may download and print one copy of any publication from the public portal for the purpose of private study or research.

- You may not further distribute the material or use it for any profit-making activity or commercial gain

- You may freely distribute the URL identifying the publication in the public portal ?

Take down policy

This is an Accepted Manuscript of an article published by Taylor \& Francis in Accounting and Business Research on 25th May 2011, available online: http://www.tandfonline.com/doi/abs/10.1080/00014788.2011.574222

Take down policy

If you believe that this document breaches copyright please contact us providing details, and we will remove access to the work immediately and investigate your claim. 
A Conceptual Framework of Impression Management: New insights from psychology, sociology, and critical perspectives

\author{
Doris M. Merkl-Davies
}

Bangor Business School, Bangor University, UK

\title{
Niamh M. Brennan
}

Quinn School of Business, University College Dublin, Ireland 


\title{
A Conceptual Framework of Impression Management: New insights from psychology, sociology and critical perspectives
}

\begin{abstract}
In this paper we develop a conceptual framework, based on the concepts of rationality and motivation, which uses theories and empirical research from psychology/behavioural finance, sociology and critical accounting to systematise, advance and challenge research on impression management. The paper focuses on research which departs from economic concepts of impression management as opportunistic managerial discretionary disclosure behaviour resulting in reporting bias or as 'cheap talk'. Using alternative rationality assumptions, such as bounded rationality, irrationality, substantive rationality and the notion of rationality as a social construct, we conceptualise impression management in alternative ways as (i) self-serving bias, (ii) symbolic management and (iii) accounting rhetoric. This contributes to an enhanced understanding of impression management in a corporate reporting context.
\end{abstract}

Keywords: Discretionary narrative disclosures, Impression management, Rationality. 


\section{A Conceptual Framework of Impression Management: New insights from psychology, sociology and critical perspectives}

\section{INTRODUCTION}

The aim of this paper is to identify and challenge assumptions on the rationality and motivation for managerial impression management, and organisational audiences' responses to it, in order to disrupt the reproduction and continuation of the line of reasoning inherent in the predominant economics-based perspective on impression in a corporate reporting context. The concept of impression management originates in social psychology and is concerned with 'studying how individuals present themselves to others to be perceived favourably by others' (Hooghiemstra, 2000, p.60). Using a dramaturgical metaphor, Goffman (1959) explains impression management as the performance of self vis-à-vis an audience. Accounting research applies the concept of impression management in a corporate reporting context to explain discretionary narrative disclosures. Management is assumed to strategically 'select... the information [in corporate narrative documents] to display and present... that information in a manner that is intended to distort readers' perceptions of corporate achievements' (Godfrey et al., 2003, p.96).

The predominant perspective on impression management in a corporate reporting context is informed by economics-based theories, particularly agency theory (Merkl-Davies and Brennan, 2007). Agency theory focuses on the relationship between managers and investors which is characterised by contractual obligations and utility maximisation. Both managers and shareholders are regarded as rational, self-interested decision-makers. This means that decision-making is assumed to correspond to mathematical models; motivation is perceived in strictly in utilitarian terms. Corporate reporting and investment decisions are taken on the basis of cost-benefit calculations and involve responding to inputs from the external environment. Since managers operate 'in an environment in which their remuneration and wealth is linked to the financial performance of the companies that employ them, managements have economic incentives to disclose messages that convey good performance more clearly than those conveying bad performance' (Rutherford, 2003, p.189). Agency theory provides a narrow view of impression management as it focuses solely on the relationship between managers and investors, focuses on reporting bias with respect to the financial performance of the firm, and conceptualises impression management as the strategic use of discretionary narrative disclosures. The role of corporate reporting in mediating the 
relationship between management and stakeholders, and biased reporting of social and environmental performance, are ignored. The relationship between managers and investors is regarded solely in terms of market exchange (Mouck, 1995).

In this paper, we put forward four explanations for discretionary narrative disclosures. (1) From an economic perspective, discretionary narrative disclosures can be regarded as: opportunistic impression management. Managers are assumed to manipulate the presentation and disclosure of information in corporate narrative documents resulting in reporting bias to mislead investors about organisational outcomes. Investors are assumed to be unable to assess the reporting bias in the short term. Alternatively, discretionary narrative disclosures can be regarded as (2) incremental information, (3) hubris, or (4) retrospective sense-making (see Figure 1 for an overview of the economic and three alternative explanations of discretionary narrative disclosures). The incremental information explanation is based on an assumption of investor rationality and semi-strong market efficiency. The efficient market hypothesis states that all market participants have rational expectations about future returns, which implies that, on average, the market is able to assess reporting bias (Hand, 1990). This assumes that biased reporting (including impression management) would lead to higher cost of capital and reduced share price performance. As managers' compensation is linked to share price performance, managers have no economic incentives to engage in impression management. Advocates of the incremental information explanation deny the existence of impression management (Baginski et al., 2000, 2004). Discretionary disclosure strategies, such as the disclosure of pro-forma earnings or the adoption of a positive tone in corporate narrative documents, are thus interpreted as useful incremental information, rather than impression management.

Biased reporting can also be due to managerial hubris. The word 'hubris' originates from ancient Greek mythology where it is used to describe the flaws (hamartia) of rulers or heroes. It refers to excessive pride in individuals which manifests itself in a sub-conscious cognitive bias. Such individuals in positions of power may irrationally take actions or make decisions that prove to be risky or grandiose, but which they believe are within their control. Corporate narratives may exhibit signs of narcissistic speak (Amernic and Craig, 2007, p. 27), a key precursor to hubris. Owen and Davidson (2009) develop a set of fourteen indicators of hubris. Individuals who exhibit three or more of these are regarded as suffering from hubris. Whereas impression management constitutes opportunistic managerial behaviour with the 
purpose of manipulating organisational audiences' perceptions of the firm and its performance, hubris constitutes self-deception or egocentric bias. Egocentric bias is ' $a$ dispositional tendency to think of oneself in a favourable light' (Barrick and Mount, 1996, p.262) and arises from the desire to protect one's self-esteem. This results in managers being biased towards their own performance. Finally, in an accountability context, particularly in the annual report, discretionary narrative disclosures may also be the result of managerial retrospective sense-making. This entails managers providing an account of organisational actions and events by retrospectively assigning causes to them (Aerts, 2005).

The objective of the paper is to identify, classify and challenge assumptions regarding the rationality and motivation of managers and organisational audiences. For this purpose, we provide a conceptual framework of impression management in a corporate reporting context. Conceptual frameworks define the main ideas in an area of study and the network of relationships between them (Callahan, 2010). Focusing on two key concepts, namely rationality and motivation, we relate relevant theories and empirical research in order to systematise, advance and challenge research on impression management. The literature is either silent, or in some cases confused, about the often implicit theoretical underpinnings and assumptions underlying the research. In particular, assumptions regarding the rationality of managers and organisational audiences, managerial motivation to engage in impression management, reasons for susceptibility to impression management, and manifestations of impression management in corporate narrative documents, are not spelled out. We develop a taxonomy based on four perspectives, namely (1) the economic, (2) the psychological/behavioural, (3) the sociological, and (4) the critical, which provide alternative ways of conceptualising impression management in a corporate reporting context (see Figures 1 and 2). The alternative perspectives put forward in the paper are not necessarily competing explanations. Rather, they represent different ways of seeing the same phenomenon.

The paper makes the following five contributions to the literature. First, the range of assumptions underlying prior research is made explicit in Section 2 of the paper and is analysed by reference to preparers and users of corporate reports in Figures 1 and 2. Second, the inconsistencies in some of these assumptions are identified in Section 2. Third, a taxonomy is put forward in Sections 3 and 4 which is split into a preparer and a user perspective. Fourth, by making the implicit assumptions of prior research explicit, we 
contribute to an enhanced understanding of impression management in a corporate reporting context. As discussed in Section 5, this can be used in future research to make predictions and interpret results (Koonce and Mercer, 2005). Finally, by identifying and challenging the assumptions underlying the predominant economics-based perspective which entails 'taking something that is commonly seen as ... natural and turning it into something problematic' (Sandberg and Alvesson, 2011, p.32) researchers can generate more informed and novel research questions such as those set out in Section 5.

Section 2 discusses the assumptions regarding rationality of managers and organisational audiences and their impact on explanations of discretionary corporate narrative disclosures. Further, the motivation for engaging in and being susceptible to impression management and their impact on the way impression management in corporate narrative documents is conceptualised is discussed. The taxonomy of prior impression management research is set out in Section 3 (preparer perspective) and Section 4 (user perspective). The paper concludes in Section 5 by considering opportunities for future research based on the insights generated from this analysis.

\section{THEORETICAL ASSUMPTIONS OF PRIOR RESEARCH}

This section contrasts the concept of economic rationality which underlies economics-based impression management research with alterative views of the decision-making and behaviour of managers and organisational audiences by discussing insights from academic disciplines concerned with 'the study of men as they live and move and think in the ordinary business of life' (Marshall, 1962; quoted in Maital, 2004, p.1), particularly cognitive and social psychology, behavioural economics/finance, sociology and critical perspectives.

\subsection{Rationality}

Economic rationality originates in rational choice theory and expected utility theory. Rational choice theory assumes that all choices are made intentionally and strictly opportunistically, taking account of the expected consequences of each choice (Zarri, 2009, p.4). Expected utility theory assumes that economic actors are highly rational utility maximisers who compute the likely effect of any action on their total wealth and choose accordingly. Economic rationality thus entails making choices which maximise satisfaction, given preferences (Zarri, 2010, p.562). 
Economic rationality is what Simon (2000, p.26) refers to as 'perfect' rationality' and Mumby and Putnam (1992, p.469) refer to as 'pure rationality'. It is prospective in the sense that it involves prospectively generating options. It is economic in the sense that the preferences of economic actors are material gain. Economic rationality thus involves prospectively selecting the best possible alternative for maximising utility. The preferences of economic agents are regarded as well-defined, stable and self-centred. All actions are driven by the desire to maximise objective utility functions. When making decisions, economic agents use all the information available (Zarri, 2009, p.1). The concept of economic rationality is not an adequate description of the behaviour of managers and investors in relation to the provision and dissemination of information in corporate narrative documents. It is abstracted from the real world which is characterised by 'uncertainty and imperfect knowledge; ambiguous and heterogeneous expectations, abilities, and preferences on the part of both management and all the groups which interact with the firm; competing and conflicting demands upon the firm; and dynamic and obscure relationships between strategies and outcomes' (Hines, 1989, p.65).

Decision-making in the real world is thus influenced by both internal and external factors, such as memory and time constraints; beliefs about oneself and others; and social rules and norms. Psychology research shows that managers and investors may suffer from cognitive and social biases and limitations which affect their decision-making. Decision-making in real-life situations is characterised by bounded, rather than pure rationality. Bounded rationality (Simon, 1972, 2000) takes into account that economic actors make decisions based on incomplete information, by exploring a limited number of alternatives, and by attaching only approximate values on outcomes (Mumby and Putnam, 1992, p.469). Decision-making in the real world is not determined by 'some consistent overall goal and the properties of the external world, [but rather] by the 'inner environment' of people's minds, both their memory contents and their processes' (Simon, 2000, p.25). This results in satisfactory, rather than optimal outcomes. Bounded rationality thus constitutes a modified form of 'pure' or economic rationality based on satisficing, rather than optimising (Mumby and Putnam, 1992). Bounded rationality explains why investors are prone to cognitive and social biases and thus are susceptible to impression management. It explains why managers may assess their own abilities in a biased manner manifesting itself in hubris -'exaggerated pride or selfconfidence' (Hayward and Hambrick, 1997, p.106). 
Both economic rationality and bounded rationality regard decision-making as a cognitive activity which excludes affective components. Research in behavioural finance and psychology suggests that emotional factors play a significant role in decision-making. For example, decision-outcomes may be enhanced by drawing on emotional resources, such as 'gut feeling'. By contrast, feelings such as anxiety and stress may negatively affect decisionoutcomes. In real-life situations, decision-making is likely to be a holistic process which combines cognitive and emotional factors (see for example Daniel et al., 2002). ${ }^{1}$

Both economic rationality and bounded rationality are types of instrumental rationality or rationality of means which involves 'applying appropriate reason to choose the best possible means to attain one's ends' (Tomer, 2008, p.1704). In this context, decisions not based on the best possible means to achieve given ends are considered irrational. Decision-making always takes place in a social context and is thus influenced by social norms and rules. This requires a shift from instrumental rationality to substantive rationality which is concerned with ideals, goals and ends which are pursued for their own sake, such as equality, justice, freedom, respect for the environment (Weber, 1968). Substantive rationality is a rationality of ends which involves applying appropriate reason to achieve these ends (Bolan, 1999, p.71). In the context of corporate reporting, substantive rationality addresses mainly social and environmental issues, such as fair trade, equality in the workplace and pollution. Firms are assumed to engage in impression management during incidents which violate social norms and rules, such as accidents (e.g., Hooghiemstra, 2000), product safety and health incidents (Elsbach, 1994) and corporate scandals (Breton and Cote, 2006; Linsley and Kajüter, 2008). In addition, critical researchers regard the notion of rationality as socially constructed (Hines, 1989; Lodh and Gaffikin, 1997). When making decisions, managers give the impression of rationality in order to be seen to conforming to the rules and norms of society and to forestall the interference of external agencies in the operation of the organisation (Hines, 1989). This may entail the use of accounting logic (Broadbent, 1998) to persuade organisational audiences of the validity and necessity of potentially controversial actions and decisions, such as privatisation (Craig and Amernic, 2004b, 2006, 2008).

\footnotetext{
${ }^{1}$ The dichotomy between cognitive and emotional factors can be traced back to the Cartesian model of the mind. Descartes regarded rationality and emotions to be distinct spheres (Lakoff and Johnson, 1999). However, emotions, which are associated with the realm of the body, can influence the mind.
} 


\subsection{Motivation}

Explanations of the behaviour of managers and organisational audiences are dependent on the way the relationship of the organisation with its environment is conceptualised. ${ }^{2}$ Both managers' motives to engage in impression management and investors' motives to act on the information provided can be regarded as independent of institutional and social context or dependent on it. Impression management and responses to it can thus be regarded as determined by economic (e.g., utility maximisation) or psychological (e.g., the desire to maximise rewards and minimise sanctions, peer pressure) factors or external constraints, such as social norms and rules (e.g., social legitimacy) or belief systems (e.g., capitalism).

The concept of economic rationality which underlies the majority of impression management research assumes that mangers' motives to provide corporate narrative disclosures and to engage in impression management and investors' motives to act on the information provided are driven by utility maximisation, i.e. increased compensation in the form of salary and bonuses for management and future cash flows for investors. Economic agents may engage in rational behaviour in the sense that they choose the best possible means to achieve their ends, but the ends are not necessarily 'what economists had supposed' (Camerer et al., 2003, p.1216; quoted in Zarri, 2009, p.2). Research in social psychology indicates that impression management may be motivated by the social 'presence' of others whose behaviour management is trying to anticipate (Allport, 1954, p.5). Managers may be prompted to engage in impression management anticipating that shareholders and stakeholders may otherwise respond in undesired ways, for example, in the form of unfavourable analyst reports, credit ratings, or news reports (Prakash and Rappaport, 1977) or in the form of withdrawing community support from the firm. Impression management thus serves to counteract such possible negative consequences by controlling the perceptions of organisational audiences either by biasing the presentation or disclosure of information before it is released (reporting bias) or by biasing the descriptions of causality of organisational actions and events (self-serving bias).

\footnotetext{
2 The predominant economics-based perspective on impression management is based on a closed-system concept of the organisation as 'separate from its environment and encompassing a set of stable and easily identifiable participants' (Scott and Davis, 2007, p.31). By contrast, the alternative perspectives (particularly the sociological and critical perspectives) introduced in this paper are based on an open-system concept of the organisation as being shaped, supported and infiltrated by its environment (Scott and Davis, 2007).
} 
Alternatively, managers may be prompted to engage in impression management in order to respond to the concerns of various stakeholder groups (stakeholder theory) or to conform to social rules and norms (legitimacy theory) ( $\mathrm{Ng}$ and $\mathrm{Tseng}$, 2008). Managers may adopt strategies to make their organisational processes or institutionalised practices appear to conform to social norms and rules (symbolic management) (Boland and Pondy, 1983, p.223; Ashforth and Gibbs 1990). This is particularly prevalent with respect to social and environmental reporting where managers may use rhetoric to persuade organisational audiences of the environmental credentials of the organisation (Livesey, 2002; Alexander, 2009). In this case, impression management is regarded as addressing the substantive rationality concerns of external parties. Managers may engage in impression management as a means of legitimising actions and in order to justify decisions (Hooghiemstra, 2000, Aerts and Cormier, 2009), to deflect criticism (Prasad and Mir, 2002), and to forestall interference by external parties such as trade unions, government agencies and environmental groups (Hines, 1989).

In the same vein, investor behaviour may be determined by social context and thus is driven by the behaviour of others, manifesting itself in peer pressure and group acceptance. Investment decisions can be regarded as influenced by consensus judgements and by herd behaviour. As investors operate in a social context, their decisions may be influenced by social norms and rules. This means that they may be guided by substantive rationality in the sense that they use appropriate reason to pursue ends for their own sake, such as investing in companies addressing social and environmental concerns (Nicholls and Paton, 2010).

\subsection{Concepts of impression management}

Assumptions of rationality and motivation impact on the way impression management is conceptualised. Economic rationality assumes that impression management is regarded as the result of rational purpose-driven behaviour of managers who aim to maximise their utility. It entails managers introducing reporting bias into corporate narrative documents by manipulating the presentation and disclosure of information. By contrast, if impression management is regarded as prompted by the (imagined) presence of shareholders and stakeholders who judge managerial performance, it is conceptualised as self-serving bias executed by attributing positive organisational outcomes to internal factors and negative organisational outcomes to external circumstances (Aerts, 1994, 2001; Clatworthy and Jones, 2003). 
Alternatively, if impression management is regarded as addressing the substantive rationality concerns of organisational audiences, it is conceptualised as symbolic management. Ashforth and Gibbs (1990) differentiate between substantive and symbolic management. Substantive management entails a real change in organisational processes or institutionalised practices, including corporate reporting. This includes normative, coercive or mimetic isomorphism and involves, for example, increasing the quantity and quality of environmental information provided due to stakeholder demand, increasing environmental awareness in society or environmental reporting practices by other firms. By contrast, symbolic management entails adopting strategies which make the organisation appear to respond to stakeholder concerns or to be congruent with society's norms and expectations. Symbolic management strategies include (i) espousing socially acceptable goals, (ii) redefining means as ends, and (iii) ceremonial conformity (i.e. adopting specific practices considered consistent with rational management, even though they do not improve organisational practices). Firms facing a major legitimacy threat engage in symbolic management by separating the negative event (e.g., fraud, scandal, product safety issue) from the organisation as a whole by normalising accounts (e.g., excuse, apology, justification) and strategic restructuring (e.g. executive replacement, establishment of monitors or watchdogs). Finally, if rationality is regarded as a social construct which lends legitimacy to decisions and actions, then impression management entails conveying an image of organisational rationality by means of retrospectively assigning causes to events or by means of using accounting concepts or numbers to frame managerial decisions or organisational outcomes (Aerts, 2005).

\subsection{Development of taxonomy}

We develop a taxonomy based on four theoretical perspectives to explain managerial impression management (Figure 1) and the responses of organisational audiences to impression management (Figure 2), namely (1) the economic, 2) the psychological/behavioural, (3) the sociological, and (4) the critical. These perspectives are based on different assumptions regarding the type of rationality underlying the behaviour of managers and organisational audiences and the motivation for providing discretionary corporate narrative disclosures. They result in conceptualising discretionary narrative disclosures in corporate narrative documents, including impression management, in different ways. 
As set out in the introduction, there are four explanations for discretionary corporate narrative disclosures: (1) incremental information, (2) impression management, (3) hubris, and (4) retrospective sense-making. One strand of research denies the existence of impression management and regards discretionary narrative disclosures as incremental information provided to aid investor decision-making. If both managers and investors are driven by economic rationality, managers have no motivation to engage in earnings management (and by extension impression management), as investors are able to 'undo' (Healy and Wahlen, 1999, p.369) reporting bias. Rather, managers are assumed to engage in unbiased reporting as this enhances managerial reputation and compensation (Baginski et al., 2000). ${ }^{3}$ Alternatively, if managers are assumed to be driven by economic rationality and investors by bounded rationality, discretionary narrative disclosures constitute impression management. In this scenario, self-interested managers are assumed to exploit information asymmetries by releasing biased information. They may then benefit from increased compensation, via share options (Adelberg, 1979; Rutherford, 2003; Courtis, 2004a). Cognitive constraints render investors unable to undo reporting bias. As a result, they revise their expectations regarding future cash flows, resulting in short-term capital misallocations. Finally, if managers are assumed to be driven by bounded rationality which biases them towards their own abilities and performance, discretionary narrative disclosures are regarded as hubris.

Following an economics-based perspective, managerial performance attributions in corporate narrative documents are assumed to constitute incremental information. Managers have strong incentives to engage in unbiased reporting, as it enhances their reputation and compensation (Baginski et al., 2000) and investors weigh disclosures by the credibility of their sources (Kothari et al., 2009). For example, the purpose of performance attributions in management forecasts is to hasten the investor expectation adjustment process. By contrast, Staw et al. (1983) and Lee et al. (2004) assume that rational utility-maximising managers use self-serving performance attributions in corporate narratives in order to manipulate investor perceptions of the financial performance of the firm. In a corporate reporting context, the focus is on organisational outcomes which may either be attributed to internal factors (i.e. ability, knowledge) or to external circumstances (i.e. macro-economic factors, competition). Attributions are assumed to be biased, if positive organisational outcomes are attributed to

\footnotetext{
${ }^{3}$ Another strand of research does not deny the existence of impression $m$ management, but regards reporting bias as 'cheap talk' (Benabou and Laroque, 1992) which is ignored by investors (see Figure 2).
} 
internal circumstances and negative organisational outcomes to external circumstances. Investors are assumed to be susceptible to impression management and thus exhibit bounded rather than economic rationality.

Psychological explanations of discretionary corporate narrative disclosures are based on attribution theory (Heider, 1958; Jones and Davis, 1965; Kelley, 1967). Attribution theory is concerned with people's explanations of events. Biased performance attributions are regarded as motivated either by socio-psychological or by cognitive-psychological factors. The first interprets biased performance attributions as impression management arising from the anticipation of potential negative consequences of information releases. This drives managers to selectively manipulate the descriptions of causality of performance attributions resulting in self-serving bias. The second regards biased performance attributions as egocentric bias or hubris arising from the cognitive dissonance between self-image and the evidence of performance. It reflects a genuine but biased self-assessment arising from a desire to protect one's self-image. Egocentric bias is the result of managerial overconfidence or optimism, rather than a deliberate attempt on the part of management to present organisational performance in the best possible light (Frink and Ferris, 1998).

Alternatively, attributions may serve an explanatory, rather than a self-serving function. Due to people's desire to achieve some control over the social world, they explain events by means of cause-effect relationships (Forsyth, 1980). In a corporate reporting context this is referred to as retrospective sense-making (Aerts, 2005). Performance attributions in corporate reports may be used (i) proactively to shape organisational audiences' perceptions of organisational outcomes and events (impression management); (ii) to protect, maintain, or further beliefs about the self or the organisation (hubris) or (iii) retrospectively to provide an account of events (retrospective sense-making). This entails the use of retrospective, rather than prospective rationality. Instrumental rationality is prospective in the sense that it entails prospectively selecting relevant causal factors and desired outcomes based on a comprehensive understanding of the situation (Boland and Pondy, 1983). By contrast, retrospective rationality entails the ex-post rationalisation of decisions in order to give the impression of rational decision-making (Aerts, 2005). As the psychological perspective regards market participants as characterised by bounded rationality, investors are assumed to be susceptible to impression management. 
Sociological explanations of discretionary corporate narrative disclosures are based on legitimacy theory, stakeholder theory and institutional theory and regard managerial disclosure behaviour as responding to stakeholder concerns and as a means of demonstrating organisational legitimacy. Whereas economic and psychological concepts of impression management regard the concerns of organisational audiences with corporate narrative reports as driven by instrumental rationality, sociological interpretations see them as motivated by substantive rationality. Impression management arises in situations where the norms and values of the firm are inconsistent with those of society (Luft Mobus, 2005, p.495). This causes managers to engage in symbolic management (Ashforth and Gibbs, 1990) to (re)establish social legitimacy. As the sociological perspective is concerned with the role of corporate narrative reports in demonstrating the organisation's congruence with social norms and values, it makes no assumptions regarding the instrumental rationality of organisational audiences and thus their susceptibility to impression management.

Critical perspectives on discretionary corporate narrative disclosures regard the notion of rationality as socially constructed in the sense that rationality 'does not intrinsically exist in a decision or situation, but is socially conferred upon it' (Hines, 1989, p.66). Rationality may be viewed as socially constructed meaning which provides sets of rules for meaningful action. Rationality is a normative construct of acceptable behaviour in organisations (Mumby and Putnam, 1992). When making decisions, managers have to be seen to be acting rationally. In this context, impression management entails presenting an image of the organisation as a rational entity, often by means of rationalising decisions in order to gain or maintain social legitimacy. This involves presenting organisational outcomes and events in corporate narrative documents as resulting from intentional, reasoned and goal-directed behaviour (Mumby and Putnam, 1992).

All four perspectives are based on different concepts of impression management. The economics-based perspective views impression management as inconsistencies between reported and actual organisational outcomes and thus conceptualises it as reporting bias. The psychology-based perspective views impression management as inconsistencies between reported and actual performance attributions and regards it as self-serving bias. Systemsoriented theories regard impression management as inconsistencies between portrayed and actual values and conceptualise it as symbolic management. Critical perspectives regard impression management as inconsistencies between portrayed and actual organisational 
decision-making. Impression management is thus conceptualised as retrospective rationality and accounting rhetoric.

\section{THEORETICAL PERSPECTIVES ON MANAGERIAL IMPRESSION MANAGEMENT}

In this section we consider the four perspectives on managerial impression management summarised in Figure 1.

The assumptions of the predominant economic perspective on managerial impression management with respect to decision-making and motivation are contrasted with those of three alternative perspectives, namely cognitive and social psychology, sociology and critical perspectives. This enriches our understanding of impression management in a corporate reporting context by providing us with alternative explanations of managerial impression management.

Figure 1 illustrates that altering assumptions of managerial rationality from 'pure' rationality to bounded rationality results in biased discretionary narrative disclosures to be conceptualised as hubris, rather than impression management. By contrast, altering assumptions of managerial motivation from opportunistic (material self-interest in the form of increased compensation) to informational (decreasing the cost of capital by means of improved decision-making) results in an alternative explanation of discretionary narrative disclosures as useful incremental information, rather than impression management. Switching from instrumental rationality to substantive rationality or rationality as a social construct leads to alternative concepts of impression management as symbolic management or retrospective rationality and accounting rhetoric.

Insert Figure 1 about here.

\subsection{Economic perspective}

The economic perspective regards impression management as a strand of the financial disclosure literature. Impression management is conceptualised as biased discretionary narrative disclosures. Managers and investors are assumed to strategically compete for wealth and thus use the information in corporate narrative documents as a factor of production with respect to that wealth (Arrington and Puxty, 1991, p.34). Impression management thus entails 
managers taking advantage of information asymmetries by means of manipulating the presentation and disclosure of information with the purpose of maximising their personal wealth (Adelberg, 1979; Rutherford, 2003; Courtis, 2004a). Corporate narrative documents serve as impression management vehicles to present a self-interested view of corporate performance (Bettman and Weitz, 1983, p.166-167; Staw et al., 1983, p.584; Abrahamson and Park, 1994, p.1302; Mather et al., 2000, p.68; Clatworthy and Jones, 2006, p.493). As negative organisational outcomes may give rise to conflicts of interest between managers and shareholders, managers are assumed to 'distort readers' perceptions of corporate achievements' (Godfrey et al., 2003, p.96) by means of obfuscating failures and emphasising successes (Adelberg, 1979, p.187).

\subsection{Social psychology perspective}

The social psychology concept of impression management originates in Goffman's (1959) dramaturgical metaphor of individuals as actors on a stage performing for an audience. Impression management is neither the result of rational decision-making which takes the expected consequences of each choice into account, nor entirely motivated by material gain. By contrast, it is regarded as embedded in and dependent on management's relationship with organisational audiences. As it arises from 'the actual, imagined and implied presence' (Allport, 1954, p.5) of organisational audiences to whom management is accountable, it is inherently social in character. Schlenker et al. (1994, p.634) define accountability as 'the condition of being answerable to audiences for performing up to certain standards, thereby fulfilling responsibilities, duties, expectations, and other charges'. On the one hand, accountability entails the obligation of one party to provide explanations and justifications for its conduct to another party. On the other hand, it involves the first party's behaviour being subject to the scrutiny, judgment and sanctioning of the second party. Accountability involves three components which affect judgement and decision-making in different ways, namely (1) the inquiry component, (2) the accounting component, and (3) the verdict component (Schlenker, 1997). The inquiry component entails anticipating or submitting to an inquiry by an audience who evaluates one's actions and decisions in relation to specific prescriptions. The accounting component involves presenting one's version of events. This gives the individual the opportunity to describe, document, interpret and explain relevant information with the purpose of constructing a personal account of events and providing reasons for their occurrence. The verdict component entails the audience delivering a verdict. This comprises both a judgment of the individual and the application of either social and material rewards or 
sanctions. The experience or anticipation of an evaluative appraisal is crucial to the concept of accountability.

Managers are accountable to organisational audiences, including shareholders and arguably stakeholders, for their decisions and actions. Corporate reports, particularly the annual report, serve as an accountability mechanism which addresses the concerns of external parties (Stanton and Stanton, 2002). In a corporate reporting context characterised by conditions of accountability, impression management arises from the inquiry component of the corporate reporting process. Management engages in impression management in anticipation of an evaluation of its actions and decisions primarily by shareholders and serves to counteract undesirable consequences. If corporate narrative documents are regarded as a description of the decision behaviour of management and thus reflect managerial performance (Prakash and Rappaport, 1977, p.35), then managers may be prompted to engage in impression management to counteract undesirable consequences of information releases in the form of unfavourable analyst reports and credit ratings, negative share price movements and loss of stakeholder support (Merkl-Davies et al., 2011).

Impression management takes place in the accounting component of the accountability process where its manifests itself in strategies adopted by management to present a version of events aimed at winning social and material rewards and avoiding sanctions. This entails the use of self-serving bias (Aerts, 1994, 2001; Clatworthy and Jones, 2003). Research suggests that, in an interactive context, people's attribution of actions and events is biased in the sense that they take credit for success and deny responsibility for failure (Knee and Zuckerman, 1996).

In contrast, Aerts (2005) argues that the accountability context of corporate annual reporting prompts managers to engage in retrospective sense-making. This concept originates in Weick's (1995) work on organisational sense-making and refers to the interpretation of events that have already occurred. The analysis by Merkl-Davies et al. (2011) of UK chairmen's statements focuses on the linguistic manifestations of the psychological processes underlying the inquiry component of the corporate reporting process which is characterised by the managerial anticipation of the feedback effects of information. They find that managers do not use chairmen's statements for impression management purposes, but to engage in sense-making by means of retrospective framing of organisational outcomes. 
Alternatively, managerial information processing may be characterised by bounded rationality. When accounting for organisational outcomes managers may provide biased performance explanations in order to enhance their own self-esteem by means attributing positive organisational outcomes to their own efforts and negative organisational outcomes to external factors beyond their control (egocentric bias). This egocentric bias serves the purpose of protecting, maintaining, or extending their beliefs about themselves or about their environment ' which would be rejected if attributions followed from observations in a strictly rational manner' (Forsyth, 1980, p.185). In the accounting literature, this egocentric bias is referred to as overconfidence bias or hubris. Hubris manifests itself in managerial optimism about future outcomes, overconfidence about forecasting ability and assigning too much weight to confirming than disconfirming evidence. Hubris is a concept which has been predominantly applied in explaining managerial dispositions and motives for mergers. Liu and Taffler (2008) investigate managerial optimism in the CEO discourse of Securities and Exchange Commission 8k filings of firms engaged in mergers or takeovers as a proxy for managerial overconfidence.

\subsection{Sociology perspective}

The sociology perspective regards corporate narrative reporting as determined by structural constraints exerted either by different stakeholder groups or by society at large. Decisionmaking and action are regarded as being affected by 'the dictates of consensually developed systems of norms and values, internalised through socialisation' (Granovetter, 1985, p.483). Decision-making is driven by substantive, rather than instrumental rationality. Stakeholder theory regards impression management as an attempt on the part of management to react to the concerns of various stakeholder groups or to respond to public pressure and media attention (Hooghiemstra, 2000). Legitimacy theory regards impression management as arising from inconsistencies between the firm's and society's norms and values. It constitutes an attempt on the part of management to gain or restore organisational legitimacy by seemingly aligning the firm's norms and values with that of society, particularly in situations where firms face legitimacy threats, such as corporate scandals, product safety issues and environmental disasters.

As described earlier, firms engage in symbolic management to give the impression that their activities are congruent with society's norms and values. Symbolic management strategies 
include (i) espousing socially acceptable goals, (ii) redefining means as ends, (iii) ceremonial conformity (i.e. adopting specific practices considered consistent with rational management, even though they do not improve organisational practices), and (iv) separating negative events or organisational outcomes from the organisation as a whole. When organisations are involved in major legitimacy threatening events, such as an environmental disaster, a fraud, or a product recall, they aim to portray the incident as an isolated event (Suchman, 1995). For this purpose, they provide normalising accounts and engage in strategic restructuring. Normalising accounts are verbal remedial strategies, such as justifications, excuses and apologies whose purpose is to repair organisational legitimacy and reputation. Strategic restructuring entails the organisation "selectively confess[ing] that limited aspects of its operations were flawed" (Suchman, 1995, p.598) and then decisively and visibly remedying the flawed operations. This is achieved by introducing small and narrowly tailored changes, such as creating monitors and watchdogs, and symbolically distancing the organisation from negative influences by disassociation, for example, by executive replacement. Espousing socially acceptable goals involves, for example, claiming customer-focus or equal opportunities employer status, when, in effect, the opposite is the case. Redefining means as ends involves recasting the meaning of its ends or means, for example by justifying the closure of employee pension schemes on the basis of the introduction of a new accounting standard. Finally, an example of ceremonial conformity is public sector organisations producing extensive annual reports in an attempt to emulate reporting practices in the private sector or organisational restructuring to distance the organisation from a negative event, such a financial fraud (Linsley and Kajüter, 2008).

Impression management in a corporate reporting context is regarded as an attempt to affect the public's perceptions of the company (Hooghiemstra, 2000, Aerts and Cormier, 2009), either by proactively shaping stakeholders' impressions of the organisation (i.e., organisational change in the form of structural organisation or privatisation; e.g. Arndt and Bigelow, 2000) or by reactively responding to stakeholder concerns, increased scrutiny by the media, or public pressure in the wake of a corporate scandal or environmental disaster (e.g., Elsbach, 1994; Hooghiemstra, 2000; Breton and Cote, 2006; Linsley and Kajüter, 2008; Lightstone and Driscoll, 2008; O’Keefe and Conway, 2008). 


\subsection{Critical perspective}

The critical perspective questions assumptions of instrumental rationality which underlies mainstream impression management research. Corporate reporting decisions are assumed not to be primarily driven by self-interested utility maximisation, but are ideological in the sense that corporate narrative documents "privilege...language and thought rooted in managerial capitalism" (Craig and Amernic, 2004a, p.814), while marginalising the perspective of other stakeholders.

If rationality is a social construct, managers may use corporate narrative documents to give the impression of rational decision-making. Organisational legitimacy is achieved by conforming to social ideologies of rational decision-making. In this scenario, impression management arises from the desire to be seen to conform to the rules and norms of society and to forestall the interference of external agencies in the operation of the organisation (Hines, 1989). Similarly, Mumby and Putnam (1992) argue that rationality is a normative construct of acceptable behaviour in organisations. In order to gain or maintain social legitimacy, managers have to present organisational outcomes and events in corporate narrative documents as resulting from intentional, reasoned and goal-directed behaviour. This involves constructing a retrospective account of organisational outcomes and events and providing reasons for their occurrence (Aerts, 2005). Retrospective rationality thus restores social legitimacy of organisational agents as rational decision-makers. In a longitudinal study of Amcor's annual reports, White and Hanson (2000, p.307) note that 'the more uncertain the general environment became, the more ... Amcor intensified its self-presentation as rational'.

Management may use rationality to justify actions and decisions. For this purpose, management may use accounting numbers and concepts to frame managerial decisions or organisational outcomes. Due to its emphasis on objectivity, measurability and lack of ambiguity, the use of 'accounting rhetoric' (for example, Craig and Amernic, 2004a; Hanson and White, 2003) or 'accounting logic' (Broadbent, 1998) lends validity, legitimacy and credibility to managerial decisions and actions. Organisational legitimacy is achieved by conforming to social ideologies of rational decision-making. Impression management thus entails the use of rationality to obscure 'the 'real' decision processes which are political" (Jones, 1992, p.235). For example, in their analysis of the discourse of privatisation in the annual letters to shareholders of Canadian National Railway, Craig and Amernic (2008, p.1087) demonstrate how accounting performance measures and accounting language "have 
been invoked to show that the vision of the promoters of the privatisation has been achieved, and that the decision to privatise has been a sagacious one".

Corporate narrative documents are used by managers to establish and maintain unequal power relationships in society in the way that they represent things and position people. Language is regarded as a medium through which prevailing power relations are articulated. Managers are regarded as powerful organisational actors who use corporate narrative documents to provide a hegemonic account of organisational outcomes, often by means of using dominant discourses. For example, in their analysis of 2001 Southwest Airlines' Letter to Shareholders, Amernic and Craig (2004) highlight how management appropriates symbolic representations to show their company in a positive light. They demonstrate the use of language in corporate narrative documents to be political.

\section{THEORETICAL PERSPECTIVES ON RESPONSES TO IMPRESSION MANAGEMENT}

A taxonomy capturing the user perspective which mirrors that of the preparer perspective is developed in Figure 2. This taxonomy consists of four perspectives: the two predominant perspectives derived from (1) economics and (2) behavioural finance/economics; and two alternative perspectives grounded in (3) sociology and (4) critical theories.

Figure 2 illustrates that the assumption of 'pure' investor rationality results in reporting bias to be conceptualised as 'cheap talk' which is ignored by investors. ${ }^{4}$ Under assumptions of bounded investor rationality, impression management results in short-term revisions of expectations about future cash flows. As shown in Figure 1, switching from instrumental rationality to substantive rationality and rationality as a social construct leads to alternative concepts of impression management as either symbolic management or retrospective rationality and accounting rhetoric. This also goes hand-in-hand with widening the concept of organisational audiences to include various stakeholder groups and the general public.

Insert Figure 2 about here.

\footnotetext{
${ }^{4}$ The reporting bias may either be due to impression management or due to managerial hubris.
} 


\subsection{Economics perspective}

Mainstream finance theories assume that investors behave rationally and that share prices incorporate information about the firm in a timely and unbiased manner. Under agency theory, investors can take for granted that managers act in their self-interest, rationally responding to incentives shaped by compensation contracts, the market for corporate control and other corporate governance mechanisms. The rational actor model assumes that people unemotionally maximise expected utility functions (Huang, 2003, p.2). In semi-strong capital markets, rational investors are assumed to regard biased information disclosures as "cheap talk' (Benabou and Laroque, 1992) and ignore them, as such disclosures are costless to managers and difficult to verify. Demers and Vega (2010) find that investors disregard managerial optimism in earnings announcements, unless it is verified by outside sources such as financial analysts and the media, and it is accompanied by hard information.

\subsection{Behavioural finance/economics perspective}

Investors are only susceptible to impression management if their decision-making is considered to be characterised by bounded rationality. This renders investors unable to assess reporting bias due to a variety of cognitive, social and emotional biases. The concept of bounded rationality originates in cognitive psychology and is used in behavioural finance/economics research to study decision-making under risk and uncertainty (Kahneman and Tversky, 1979). Bounded rationality results in investors being unable to assess information in an unbiased and timely manner due to time constraints and cognitive and affective biases, such as hindsight bias, the primacy/recency effects (individuals more influenced by the first/last information item (Einhorn and Hogarth 1981)) and the bandwagon effect (see Olsen (1998) for a full list of biases impacting on investor decision-making). The incomplete revelation hypothesis views time constraints on the part of investors as a factor in investor susceptibility to impression management (Bloomfield, 2002). Information that is more costly to extract from publicly available data is less completely reflected in market prices. The easier information is to extract, the more it is impounded into share prices. Bowen et al. (2005) use the incomplete revelation hypothesis to explain investor reactions to impression management in the form of emphasising income-increasing pro-forma earnings numbers. They find that firms with low value relevance of earnings and greater media exposure place less emphasis on GAAP earnings and greater relative emphasis on pro forma earnings (i.e., they visually direct readers' attention to the earnings number which shows financial performance in the best possible light). Li (2008) also invokes the incomplete 
revelation hypothesis to explain why managers may choose to manipulate syntactic features to render the annual reports of poorly performing firms difficult to read in order to increase the time and effort for investors to extract information. The belief-adjustment model (Einhorn and Hogarth 1981) suggests that information processing is affected by the ordering of information. Investors may be either biased towards information presented first (primacy effect) or towards information presented last (recency effect). Thus, investors may attribute less weight to bad news and more weight to good news, depending on the order in which they are presented. Baird and Zelin (2000) test the belief-adjustment model and find that the ordering of good and bad news can influence investor perceptions. Evidence on how unsophisticated investors cognitively process pro forma earnings information is provided by Fredrickson and Miller (2004). Cognitive processes are divided between information acquisition and information evaluation. They find that investors are subject to unintentional cognitive biases, rather than consciously perceiving information to be informative. These unintentional cognitive biases are attributed to cognitive limitations arising from their lack of expertise and the use of ill-defined valuation models. Krische (2005) also finds unintentional investor evaluation effects arising from memory limitations. Similar to Krische (2005), Elliott (2006) attributes unsophisticated investor responses to the emphasis of pro forma earnings to unintentional cognitive effects. She posits that investors may overweigh a less important cue simply because it is emphasised. Managers exploit this salience effect to influence investor perceptions of organisational outcomes by emphasising the earnings metric that portrays financial performance in a positive light.

The investor decision-making process is driven not only by the quality of securities' underlying technical fundamentals, but also by affective evaluation (MacGregor et al., 2000; MacGregor, 2002; Pixley, 2002; Dreman, 2004). MacGregor et al. (2000) and MacGregor (2002) find that affective evaluation is based on the image associated with a particular company. In particular, MacGregor (2002) finds image evaluations to be correlated with financial judgments. Firms can exploit this association to their advantage by pro-actively manipulating their image and thus the perceptions of firm performance and prospects. The emotional impact of presentational effects has been studied in the context of visual information. Courtis (2004b) examines the effect of colour in annual reports and finds that some colours are associated with more (or less) favourable perceptions and investment judgements. However, it may also be present in verbal information, as language is an ideal medium for conveying emotion (MacGregor, 2002, p.20). Thus, readers of corporate 
narrative documents may be influenced by emotionally charged language, particularly similes, metaphors and other rhetorical figures. Cianci and Kaplan (2010) consider the influence of trust on investors' judgements of management explanations for poor firm performance. They examine the influence of CEO reputation and the plausibility of management explanations, finding that investor judgements are not influenced by CEO reputation.

\subsection{Sociology perspective}

The sociological perspective conceptualises impression management as symbolic management. Symbols manipulate audience's perceptions of the congruence of organisational practices with social norms and rules. The focus of analysis is on perceptions of organisational legitimacy. Research investigates the impact of impression management relating to organisations' environmental performance on organisational audiences. Archival research predominates. This entails assessing shareholder perceptions by means of share price reactions and stakeholder perceptions by means of media accounts. Applying institutional theory, Bansal and Clelland (2004) investigate shareholder responses to corporate environmental legitimacy and impression management relating to environmental performance (disclosure of environmental liabilities and expression of environmental commitment). Investors are assumed to assess corporate environmental legitimacy according to the firm's conformity to accepted social structures. They find that firms which adopt institutional norms gain legitimacy which lowers their unsystematic stock market risk. Berrone et al. (2009) investigate organisational audiences' perceptions of corporate environmental legitimacy. They find that symbolic management does not have the same impact on environmental legitimacy compared to substantive management. They conclude that symbolic management is not unimportant in the sense that symbolic and substantive management are complementary rather than supplementary.

\subsection{Critical perspective}

We are unaware of accounting research exploring whether readers of corporate narrative documents are persuaded by the use of retrospective rationality and accounting rhetoric to give the impression of rational decision-making and/or to persuade organisational audiences about the validity and legitimacy of managerial actions and decisions. Research in linguistics suggests that rhetoric constitutes an effective means of giving universal status to particular discourses, for example the discourse of New Public Management which includes the use of 
accounting rhetoric to persuade audiences of the advantages of a market orientation in the public sector (Fairclough, 2003). If audiences are persuaded by the use of accounting concepts and numbers in corporate narrative documents to justify managerial actions and decisions, this reinforces the status quo by promoting ignorance in the sense that 'the company maintain $[s]$ a privileged position regarding information by keeping society unaware of alternative avenues of consumption, or systems of organisation or its present and future performance' (Simpson, 2000, p.245).

\section{IMPLICATIONS FOR FUTURE RESEARCH}

This paper commenced with a criticism of the narrow concept of economic rationality which underlies the predominant economics-based approach to impression management research (Merkl-Davies and Brennan, 2007). Research based on economic rationality assumes that the decision-making of organisational actors and audiences involves taking the expected consequences of each choice into account and that these decisions are driven by selfinterested utility-maximisation. This is reductionist in the sense that managerial corporate reporting decisions and responses to these decisions are regarded as abstracted from real decision-making, driven by a narrow view of human behaviour based on prospective rationality and motivated solely by material gain.

We introduce alternative concepts of impression management based on theories from psychology/behavioural finance, sociology and critical perspectives which are based on different assumptions regarding the rationality and motivation of managers and organisational audiences. These inform the way discretionary corporate narrative disclosures are interpreted and the way impression management is conceptualised. By making these underlying assumptions explicit, we contribute to the quality of future research by highlighting the importance of consistency between underlying assumptions, predictions and interpretations of results. Identifying, classifying and challenging assumptions regarding the rationality and motivation of managers and organisational audiences may help researchers to think differently about what is already known (Foucault, 1985).

\subsection{Concepts of impression management}

Depending on the theoretical perspective adopted and the focus of analysis (i.e. management versus organisational audiences), impression management is conceptualised as opportunistic managerial discretionary disclosure behaviour, reporting bias, self-serving bias, symbolic 
management and cheap talk. Insights from psychology, sociology and critical perspectives show impression management as a multifaceted and complex phenomenon aimed at shaping the perceptions of a wide range of outside parties. Sociological and critical approaches shift the focus of analysis away from specific impression management tactics to broader strategies used to present a particular version of events, such as rhetoric (see, for example, Driscoll and Crombie, 2001; Livesey, 2002; Craig and Amernic, 2004b, 2006, 2008) or symbolic management (see, for example Linsley and Kajüter, 2008). This necessitates a more qualitative, in-depth analysis of corporate narrative documents aimed at uncovering how impressions are constructed.

Relatively little is known about the influence of the content and presentation of corporate narrative documents on organisational audiences. Corporate report readers have been profiled in terms of their sophistication (sophisticated and unsophisticated) and their information acquisition strategies (goal directed/purposeful and incidental/random) (Courtis, 2000, p.25558; Courtis and Hassan, 2002, p.398-99). The former acquire information by seeking answers to preconceived questions and search sections of the annual report for answers to specific questions, while the latter merely browse through the annual report and read bits and pieces as take their fancy. There is little evidence on the information acquisition strategies undertaken by different strata of that audience. Nor has the relationship between information inductance, framing and impression management been adequately explored. These questions need to be addressed in future research.

\subsection{New methodological approaches}

The majority of impression management research is archival. Research on the preparer perspective is primarily based on textual analysis. The problem with archival research is that the underlying decision-processes and motivations have to be inferred. This problem may be overcome in future research by using methods which allow a more direct access to organisation actors' decision-making and motivation. The concepts introduced in this study can be used by researchers as a theoretical framework to inform their interactions with organisational actors and audiences in field studies and interviews. There is some research on the drivers of disclosures in the narrative documents of various organisations. Findings suggest that different disclosure positions may co-exist in one firm (Gibbins et al., 1990; Adams, 1997) and that disclosure positions may differ across different corporate narrative documents (Jetty and Beattie, 2009). This means that impression management forms part of 
the disclosures made within one particular narrative document, that different manifestations of impression management may co-exist in one document, and that impression management may be more prevalent in specific types of corporate narrative documents.

There is less research on the perception of narrative disclosures by organisational audiences. This is at least partly due to the difficulty of capturing the response of organisational audiences other than shareholders to impression management by conventional archival methods. Research on the user perspective predominantly focuses on shareholder responses to impression management by means of share price reaction studies. Some researchers have used experimental approaches to proxy shareholder reactions (Stanton et al., 2004; Barton and Mercer, 2005; Krische, 2005; Elliott, 2006). Bansal and Clelland's (2004) and Breton and Cote's (2006) approach of using media accounts as a proxy for public perception may be a way forward. Solomon et al. (2009) interview 20 institutional investors in relation to impression management and private social and environmental reporting. Although their focus is not on social and environmental disclosures in corporate reports, their study nonetheless provides an example of a different approach to studying investor perceptions of impression management in a corporate reporting context. They find evidence of impression management, which is of concern, since the objective of private social and environmental disclosures is to encourage relationship investing by engendering trust, confidence and transparency in the relationship between companies and their core institutional investors. In conclusion, different methodological approaches provide opportunities to address new research questions dealing with preparer and user perspectives.

\subsection{Interaction between managers and organisational audiences}

Prior research conceptualises impression management as a process consisting of two separate stages, namely (1) managerial impression management, primarily by means of corporate narrative documents, such as annual reports and press releases, and (2) audience responses to impression management. Ginzel et al. (2004) argue that impression management constitutes an interactive process between managers and audiences. The social psychology perspective of impression management introduced in Section 3.2 shows that impression management can be regarded as being triggered by the anticipation of the reactions of information recipients to managerial disclosures. Ginzel et al. (2004, p.225) argue that this 'process of reciprocal influence' between management and organisational audiences is not necessarily confined to an 'initial attempt...to explain an organisation's actions or performance'. In cases where 
impression management attempts are not successful in the sense that audiences are not convinced, the impression management process extends to a third stage during which management and audiences attempt to resolve interpretive conflicts regarding the appropriate interpretation of an event, resulting in possible modifications in interpretations. Driscoll and Crombie's (2001) analysis of a conflict between a large timber firm and a small monastery situated in a forest where the firm is operating is a rare example of a study of impression management as an interactive process between two parties. They find that the timber firm uses language and symbolic activity strategically to increase its own legitimacy and decrease the legitimacy of the convent.

\subsection{Concluding comments}

Impression management is a much richer and more complex phenomenon than suggested by the predominant economics-based perspective. Insights from disciplines conceptualising the relationship between managers and organisational audiences as going beyond market exchange and which either focus on 'real people, real behaviour, or real reason' (Maital, 2004 , p.1) relating to corporate narrative reporting or on the ideological motivation and effects of corporate narrative reporting allow us to conceptualise impression management in new ways. For this purpose, we develop a taxonomy which renders rationality assumptions and motivational components in prior research explicit and classifies prior research into four distinct perspectives based on these underlying assumptions. This allows us to advance research by assisting researchers in locating their study within a particular perspective. We also provide guidance on how to achieve consistency between assumptions, predictions and interpretation of results, leading to more informed and novel research questions depending on the impression management concepts adopted, the research methodologies applied and consideration of the interactions between preparers and users of corporate reports. 


\section{References}

Abrahamson, E. and Park, C., 1994. Concealment of negative organizational outcomes: an agency theory perspective. Academy of Management Journal, 37(5), 1302-1334.

Adams, M., 1997. Ritualism, opportunism and corporate disclosure in the New Zealand life insurance industry: field evidence. Accounting, Auditing and Accountability Journal, $10(5), 718-734$.

Adelberg, A.H., 1979. Narrative disclosures contained in financial reports: means of communication or manipulation. Accounting and Business Research, 9(35), 179-189.

Aerts, W., 1994. On the use of accounting logic as an explanatory category in narrative accounting disclosures. Accounting, Organizations and Society, 19(4/5), 337-353.

Aerts, W., 2001. Inertia in the attributional content of annual accounting narratives. The European Accounting Review, 10(1), 3-32.

Aerts, W., 2005. Picking up the pieces: impression management in the retrospective attributional framing of accounting outcomes. Accounting, Organizations and Society, $30,493-517$.

Aerts, W. and Cormier, D., 2009. Media legitimacy and corporate environmental communication. Accounting, Organizations and Society, 34(1), 1-27.

Alexander, R.J. 2009. Framing Discourse on the Environment: A Critical Discourse Approach. London, Routledge.

Allport, G.W., 1954. The historical background of social psychology. In G. Lindzey, and E. Aronson, (eds.), Handbook of Social Psychology, 1(3), 1-46.

Amernic, J.H., \& Craig, R.J., 2004. 9/11 in the service of corporate rhetoric: Southwest Airlines' 2001 letter to shareholders. Journal of Communication Inquiry, 28(4), 325-341.

Amernic, J.H. and Craig, R.J., 2007. Guidelines for CEO-speak: editing the language of corporate leadership. Strategy \& Leadership, 35(3), 25-31.

Arndt, M., and Bigelow, B., 2000. Presenting structural innovation in an institutional environment: hospital's use of impression management. Administrative Science Quarterly, 45(3), 494-522.

Arrington, C.E. and Puxty, A.G., 1991. Accounting, interests, and rationality: a communicative relation. Critical Perspectives on Accounting, 2, 31-58.

Ashforth, B. and Gibbs, B., 1990. The double-edged sword of organizational legitimation'. Organization Science, 1(2), 177-194. 
Baginski, S.P., Hassell, J.M. and Hillison, W.A., 2000. Voluntary causal disclosures: tendencies and capital market reactions. Review of Quantitative Finance and Accounting, 15(4), 371-389.

Baginski, S.P., Hassell, J.M. and Kimbrough, M.D., 2004. Why do managers explain their earnings forecasts? Journal of Accounting Research, 22(1), 1-29.

Baird, J.E. and Zelin, R.C., 2000. The effects of information ordering on investor perceptions: an experiment utilizing presidents' letters. Journal of Financial and Strategic Decisions, 13, 71-81.

Bansal, P. and Clelland, I., 2004. Talking trash: legitimacy, impression management and unsystematic risk in the context of the natural environment. Academy of Management Journal, 27(1), 93-103.

Barrick, M.R. and Mount, M.K., 1996. Effects of impression management and self-deception on the predictive validity of personality constructs. Journal of Applied Psychology, 81(3), 261-272.

Barton, J. and Mercer, M., 2005. To blame or not to blame: analysts' reactions to explanations of poor management performance. Journal of Accounting and Economics, 39(3), 509-533.

Benabou, R., and Laroque, G., 1992. Using privileged information to manipulate markets: insiders, gurus, and credibility. Quarterly Journal of Economics, 107(3), 921-958.

Berrone, P., Gelabert, L. and Fosfuri, A., 2009. The impact of symbolic and substantive actions on environmental legitimacy. Working paper 778, IESE Business School, University of Navarra.

Bettman, J. and Weitz, B., 1983. Attributions in the boardroom: causal reasoning in corporate annual reports. Administrative Science Quarterly, 28, 165-183.

Bloomfield, R., 2002. The 'incomplete revelation hypothesis' and financial reporting. Accounting Horizons, 16(3), 233-243.

Bolan, R.S., 1999. Rationality revisited: an alternative perspective on reason in management and planning. Journal of Management History, 5(2), 68-86.

Boland, R.J., and Pondy, L.R., 1983. Accounting in organizations: a union of natural and rational perspectives. Accounting Organizations and Society, 8(2/3), 223-234.

Bowen, R.M., Davis, A.K. and Matsumoto, D.A., 2005. Emphasis on pro forma versus GAAP earnings in quarterly press releases: determinants, SEC intervention and market reactions. The Accounting Review, 80(4), 1011-1038. 
Breton, G. and Cote, L., 2006. Profit and the legitimacy of the Canadian banking industry. Accounting, Auditing and Accountability Journal, 19(2), 512-539.

Broadbent, J., 1998. The gendered nature of 'accounting logic': pointers to an accounting that encompasses multiple values. Critical Perspectives on Accounting, 9(3), 267-297.

Callahan, J.L., 2010. Constructing a manuscript: distinguishing integrative literature reviews and conceptual and theory articles. Human Resource Development Review, 9(3), 300304.

Camerer, C., Issacharoff, S., Loewenstein, G., O’Donoghue, T., Rabin, M., 2003. Regulation for conservatives: behavioral economics and the case for 'asymmetric paternalism'. Pennsylvania Law Review, 151, 1211-1254.

Cianci, A.M. and Kaplan, S.E., 2010. The effect of CEO reputation and explanations for poor performance on investors' judgements about the company's future performance and management. Accounting, Organisations and Society, 35(4), 478-495.

Clatworthy, M. and Jones, M.J., 2003. Financial reporting of good news and bad news: evidence from accounting narratives. Accounting and Business Research, 33(3), 171185.

Clatworthy, M.A. and Jones, M.J., 2006. Differential reporting patterns of textual characteristics and company performance in the chairman's statement. Accounting, Auditing and Accountability Journal, 19(4), 493-511.

Courtis, J.K., 2000. Expanding the future financial corporate reporting package. Accounting Forum, 24(3), 248-263.

Courtis, J.K., 2004a. Corporate report obfuscation: artefact or phenomenon? British Accounting Review, 36(3), 291-312.

Courtis, J.K., 2004b. Colour as visual rhetoric in financial reporting. Accounting Forum, 28(3), 265-281.

Courtis, J.K. and Hassan, S., 2002. Reading ease of bilingual annual reports. Journal of Business Communication, 39(4), 394-413.

Craig, R.J. and Amernic, J.H., 2004a. Enron discourse: the rhetoric of a resilient capitalism. Critical Perspectives on Accounting, 15(6/7), 813-851.

Craig, R.J. and Amernic, J.H., 2004b. The deployment of accounting-related rhetoric in the prelude to privatization. Accounting, Auditing and Accountability Journal, 17(1), 41-58.

Craig, R.J. and Amernic, J.H., 2006. The mobilization of accounting in preening for privatization. Accounting, Auditing and Accountability Journal, 19(1), 82-95. 
Craig, R.J. and Amernic, J.H., 2008. A privatization success story: accounting and narrative expression over time. Accounting, Auditing and Accountability Journal, 21(8), 10851115.

Daniel, K., Hirshleifer, D. and Teoh, S.H., 2002. Investor psychology in capital markets: evidence and policy implications. Journal of Monetary Economics, 49, 139-209.

Demers, E. and Vega, C., 2010. Soft information in earnings announcements: news or noise? INSEA Working Paper, http://ssrn.com/abstact=1152326.

Dreman, D., 2004. The influence of affect on investor decision-making. The Journal of Behavioural Finance, 5(2), 70-74.

Driscoll, C. and Crombie, A., 2001. Stakeholder legitimacy management and the qualified good neighbor. Business \& Society, 40(4), 442-471.

Einhorn, H.J. and Hogarth, R.M., 1981. Behavioral decision theory process of judgment and choice. Annual Review of Psychology, 32, 53-88.

Elliott, W.B., 2006. Are investors influenced by pro forma emphasis and reconciliations in earnings announcements? Accounting Review, 81(1), 113-133.

Elsbach, K.D., 1994. Managing organizational legitimacy in the Californian cattle industry: the construction and effectiveness of verbal accounts. Administrative Science Quarterly, 39(1), 57-88.

Fairclough, N., 2003. Analyzing Discourse: Textual Analysis for Social Research. London, Routledge.

Forsyth, D.R., 1980. The functions of attributions. Social Psychology Quarterly, 43, 184189.

Foucault, M.A., 1985. The Use of Pleasure. A History of Sexuality. Volume 2, New York, Vintage.

Frederickson, J.R. and Miller, G.S., 2004. The effects of pro forma earnings disclosures on analysts' and nonprofessional investors' equity valuation judgments. Accounting Review, 79(3), 667-686.

Frink, D.D. and Ferris, G.R., 1998. Accountability, impression management, and goal setting in the performance evaluation process. Human Relations, 51(10), 1259-1283.

Gibbins, M., Richardson, A. and Waterhouse, J., 1990. The management of corporate financial disclosure: opportunism, ritualism, policies and processes. Journal of Accounting Research, 28(1), 121-143.

Ginzel, L.E., Kramer, R.M. and Sutton, R.I., 2004. Organizational impression management as a reciprocal influence process: the neglected role of the organisational audience. in 
Hatch, M.J. and Schultz, M. (eds), Organizational Identity, Oxford University Press, $223-261$.

Godfrey, J., Mather, P. and Ramsay, A., 2003. Earnings and impression management in financial reports: the case of CEO changes. Abacus, 39(1), 95-123.

Goffman, E., 1959. The Presentation of Self in Everyday Life. New York, Doubleday Anchor Books.

Granovetter. M., 1985. Economic action and social structure. The problem of embeddedness. American Journal of Sociology, 91(3), 481-510.

Hand, J., 1990. A test of the extended functional fixation hypothesis. Accounting Review 65(4), 764-780.

Hanson, D. and White, R., 2003. Rhetorics of environmental routinisation in one Australian company's annual reports. Australian Journal of Social Issues, 38(4), 477-493.

Hayward, M. and Hambrick, D.C., 1997. Explaining the premiums paid for large acquisitions: evidence of CEO hubris. Administrative Science Quarterly, 42(1), 103127.

Healy, P.M. and Wahlen, J.M., 1999. A review of the earnings management literature and its implications for standard setting. Accounting Horizons, 13, 365-383.

Heider, F., 1958. The Psychology of Interpersonal Relations, Wiley, New York.

Hines, R.D., 1989. The socio-political paradigm in financial accounting research. Accounting, Auditing and Accountability Journal, 2(2), 52-76.

Hooghiemstra, R., 2000. Corporate communication and impression management - New perspectives why companies engage in corporate social reporting. Journal of Business Ethics, 27, 55-68.

Huang, P.H., 2003, Regulating irrational exuberance and anxiety in securities markets, University of Pennsylvania Law School, Institute for Law and Economics, Research Paper No. 03-34.

Jetty, J. and Beattie, V., 2009. Disclosure Practices and Policies of UK Charities. Association of Chartered Certified Accountants’ Report 108.

Jones, T.C., 1992. Understanding management accountants: the rationality of social action. Critical Perspectives on Accounting, 3(3), 225-257.

Jones, E.E. and Davis, K.E., 1965. From acts to dispositions: the attribution process in person perception. in Berkowitz, L. (Ed.) Advances in Experimental Social Psychology, 2, New York, Academic Press, 219-226. 
Kahneman, D. and Tversky, A., 1979. Prospect theory: an analysis of decision under risk. Econometrica, 47(2), 263-292.

Kelley, H.H., 1967. Attribution in social psychology. Nebraska Symposium on Motivation, $15,192-238$.

Knee, C.R. and Zuckerman, M., 1996. Causality orientations, failure and achievement. Journal of Personality, 62, 321-346.

Koonce, L. and Mercer, M., 2005. Using psychology theories in archival financial accounting research. Journal of Accounting Literature, 24, 175-214.

Kothari, S.P., Li, X. and Short, J.E., 2009. The effect of disclosures by management, analysts, and business press on cost of capital, return volatility and analysts' forecasts: a study using content analysis. Accounting Review, 84(5), 1639-1670.

Krische, S.D. 2005. Investors' evaluations of strategic prior-period benchmark disclosures in earnings announcements. Accounting Review, 80(1), 243-268.

Lakoff, G. and Johnson, M., 1999. Philosophy in the flesh, the embodied mind and its challenge to Western thought. New York, Basic Books.

Lee, F., Peterson, C. and Tiedens, L.Z., 2004. Mea culpa: predicting stock prices from organizational attributes. Personality and Social Psychology Bulletin, 30(12), 1636-1649.

Li, F., 2008. Annual report readability, current earnings, and earnings persistence. Journal of Accounting and Economics, 45(2-3), 221-247.

Lightstone, K., and Driscoll, C., 2008. Disclosing elements of disclosure: a test of legitimacy theory and company ethics. Canadian Journal of Administrative Sciences, 25(1), 7-21.

Linsley, P., and Kajüter, P.M., 2008. Restoring reputation and repairing legitimacy. A case study of impression management in response to a major risk event at Allied Irish Banks plc. International Journal of Financial Services Management, 3(1), 65-82.

Liu, Y. and Taffler, R., 2008. CEO overconfidence in M\&A decision making and its impact on firm performance. Working paper.

Livesey, S.M., 2002. Global warming wars: rhetorical and discourse analytic approaches to Exxonmobil's corporate public discourse. Journal of Business Communication, 39(1), $117-146$.

Lodh, S.C. and Gaffikin, M.J.R., 1997. Critical studies in accounting research rationality and Habermas: a methodological reflection. Critical Perspectives on Accounting, 8(5), 433474.

Luft Mobus, J., 2005. Mandatory environmental disclosures in a legitimacy theory context. Accounting, Auditing and Accountability Journal, 18(4), 492-517. 
MacGregor, D.G., 2002. Imagery and financial judgment. The Journal of Psychology and Financial Markets, 3(1), 15-22.

MacGregor, D.G., Slovic, P., Dreman, D. and Berry, M., 2000. Imagery, effect, and financial judgment. The Journal of Psychology and Financial Markets, 1(2), 104-110.

Maital, S., 2004. Daniel Kahneman: on redefining rationality. Journal of Socio-Economics, $33,1-14$.

Marshall, A., 1962 Principles of Economics, $8^{\text {th }}$ edition, London, Macmillan.

Mather, P., Ramsay, A. and Steen, A., 2000. The use and representational faithfulness of graphs in IPO prospectuses. Accounting, Auditing and Accountability Journal, 13(1), $65-83$.

Merkl-Davies, D.M., and Brennan, N.M., 2007. Discretionary disclosure strategies in corporate narratives: incremental information or impression management? Journal of Accounting Literature, 26, 116-194.

Merkl-Davies, D.M., Brennan, N.M., and McLeay, S.J., 2011. Impression management and retrospective sense-making in corporate narratives: a social psychology perspective. Accounting, Auditing and Accountability Journal, 24(3), forthcoming.

Mouck, T., 1995. Financial reporting, democracy and environmentalism: a critique of the commodification of information. Critical Perspectives on Accounting, 6(6), 535-553.

Mumby, D.K. and Putnam, L.L., 1992. The politics of emotion: the feminists reading of bounded rationality. Academy of Management Review, 17(3), 465-486.

Ng, I. C. L. and Tseng, L., 2008. Learning to be sociable: the evolution of Homo Economicus. American Journal of Economics and Sociology, 67(2), 265-286.

Nicholls, A., and Paton, R. (2010), Emerging Resource Flows for Social Entrepreneurship: Theorizing Social Investment. Skoll Centre for Social Entrepreneurship Research Paper.

Olsen, R.A., 1998. Behavioural finance and its implications for stock price volatility. Financial Analysts Journal, 54(2), 10-18. 
O'Keefe, P. and Conway, S., 2008. Impression management and legitimacy in an NGO environment. Working Paper. Working paper Series No 2/2008. University of Tasmania, Australia.

Owen, D. and Davidson, J., 2009. Hubris syndrome: an acquired personality disorder? A study of US Presidents and UK Prime Ministers over the last 100 years, Brain 132(5), 1396-1406.

Pixley, J., 2002. Finance organizations, decisions and emotions. British Journal of Sociology, 53(1), 41-65.

Prakash, P. and Rappaport, A., 1977. Information inductance and its significance for accounting. Accounting, Organisations and Society, 2(1), 29-38.

Prasad, A. and Mir, R., 2002. Digging deep for meaning: a critical hermeneutic analysis of CEO letters to shareholders in the oil industry. Journal of Business Communication, $39(1), 92-116$.

Rutherford, B.A., 2003. Obfuscation, textual complexity and the role of regulated narrative accounting disclosure in corporate governance. Journal of Management and Governance, 7(2), 187-210.

Sandberg, J. and Alvesson, M., 2011. Ways of constructing research questions: gap-spotting or problematization? Organization, 18(1), 23-44.

Schlenker, B., 1997. Personal responsibility: applications of the triangle model. in Cummings, L.L. and Staw, B. (eds), Research in Organizational Behavior, 19, 241-301.

Schlenker, B.R., Britt, T.W., Pennington, J., Murphy, R., and Doherty, K., 1994. The triangle model of responsibility. Psychological Review, 101, 632-652.

Scott, W.R. and Davis, G.F., 2007. Organizations and Organizing: Rational, Natural, and Open System Perspectives. New Jersey, Pearson International.

Simon, H.A., 1972. Administrative Behaviour, Free Press, New York.

Simon, H.A., 2000. Bounded rationality in social science: today and tomorrow. Mind and Society, 1, 25-39.

Simpson, L., 2000. The annual report: an exercise in ignorance? Accounting Forum, 24(3), 231-247.

Solomon, J.F., Solomon, A., Joseph, N.L. and Norton, S.D., 2009. Impression management, concealment and power in private social and environmental reporting. Paper presented at the European Accounting Association Annual Congress, Tampere, Finland.

Stanton, P. and Stanton, J., 2002. Corporate annual reports: research perspectives used. Accounting, Auditing and Accountability Journal, 15(4), 478-500. 
Stanton, P., Stanton, J. and Pires, G., 2004. Impressions of an annual report: an experimental study. Corporate Communications: An International Journal, 9(1), 57-69.

Staw, B.M., McKechnie, P.I. and Puffer, S.M., 1983. The justification of organisational performance. Administrative Science Quarterly, 28, 582-600.

Suchman, M.C., 1995. Managing legitimacy: strategic and institutional approaches. Academy of Management Research, 20(3), 571-610.

Tomer, J., 2008. Beyond the rationality of economic man: toward the true rationality of human man. Journal of Socio-Economics, 37(5), 1703-1712.

Weber, M., 1968. Economy and Society. 3 Volumes. Towata, Bedminster Press.

Weick, K., 1995. Sensemaking in Organizations. London, Sage.

White, R. and Hanson, D., 2000. Rationality and rhetoric in the corporate world: the corporate annual report as an Aristotelian genre. Prometheus, 18(3), 303-317.

Zarri, G.P., 2009. Representation and Management of Narrative Information, Theoretical Principles and Implementation, Springer-Verlag, London.

Zarri, G.P., 2010. Behavioral economics has two 'souls': Do they both depart from economic rationality?. The Journal of Socioeconomics, 39(5), 562-567. 
Figure 1: Contrasting predominant and alternative perspectives on managerial impression management

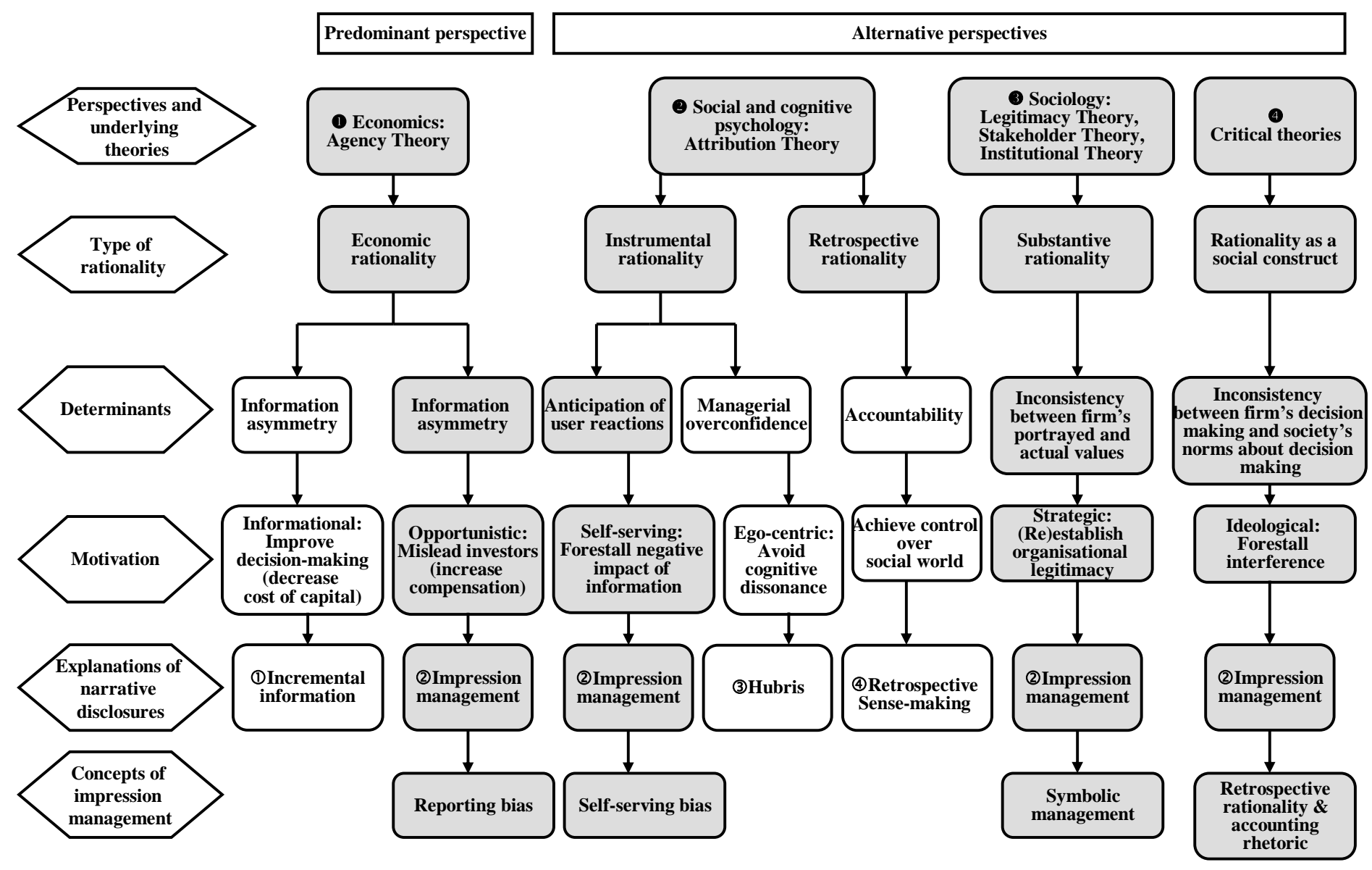

Key: Shading represents impression management, the primary focus of this paper 
Figure 2: Contrasting predominant and alternative perspectives on responses to impression management

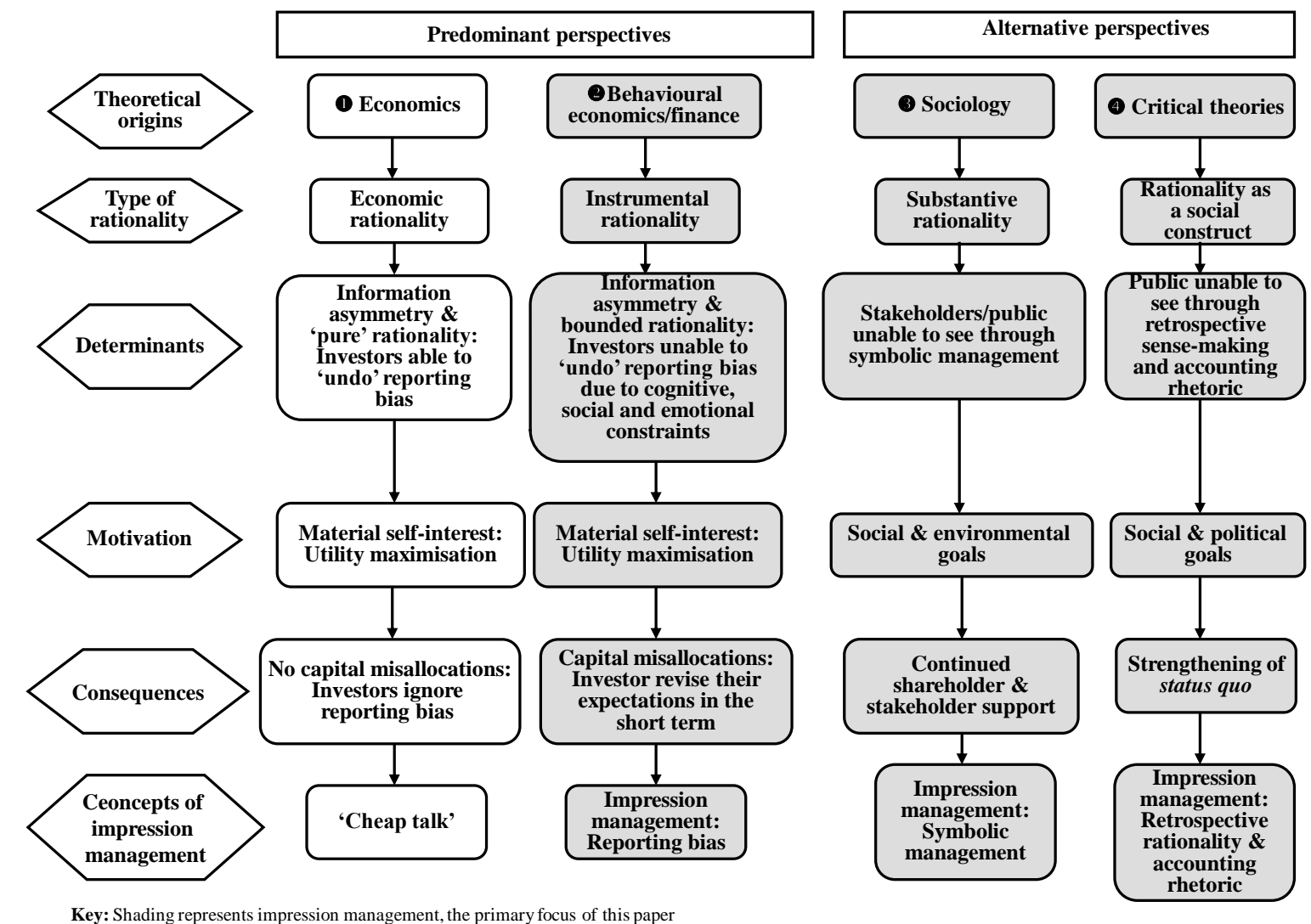

